\title{
Epidemiology Report
}

\section{Excretion and transmission of JCV in human populations}

\author{
Sílvia Bofill-Mas and Rosina Girones \\ Department of Microbiology, University of Barcelona, Barcelona, Spain
}

\begin{abstract}
The potential transmission of JCV through the environment has been analyzed by studying the JC viruses present in raw sewage of urban populations from widely divergent geographical areas. High numbers of JCV were found. JCV was detected in $98 \%(51 / 52)$ of sewage samples from different geographical areas in Europe, Africa, and USA by applying a Nested-PCR procedure. The mean estimated concentration of JCV in sewage was of $10^{2}-10^{3}$ viral particles $/ \mathrm{ml}$. Sequence analysis shows that JCV found in environmental samples present an archetypal structure in the regulatory region as it has been described in urine samples. Cerebrospinal fluid samples (CSF) of PML (progressive multifocal leucoencephalopathy) patients were also analyzed as control samples in this study presenting tandem repeats and rearrangements at the regulatory region (RR). Sequence analysis of the intergenic region (IGR) allowed the typification and phylogenetic analysis of the JCV sequences detected in sewage. JC viral particles were also found to be stable in sewage samples at $20^{\circ} \mathrm{C}$ for more than 70 days. This data suggest the idea that the intake of water or food contaminated with JCV could constitute a portal of entry for the virus or the viral DNA to the human organism. Journal of NeuroVirology (2001) 7, 345-349.
\end{abstract}

Keywords: excretion; JC virus DNA; polluted food; polluted waters; polymerase chain reaction; sequence analysis

Human polyomaviruses (BK and JC) are frequently shed in urine as they persistently infect the kidneys of infected people. JCV has been detected in 20$80 \%$ of the adult urines tested, depending on the ethnic group (Agostini et al, 1997) and on the age (Kitamura et al, 1994). JCV is the causative agent of PML, it has also been related to some human glial tumors (astrocytomas, ependymomas, oligodendrogliomas, glioblastomas) although there is no direct evidence for tumorigenesis of JCV in the human brain. JC viral DNA has also been described in the intestinal epithelia and could be related to human colorectal cancer (Laghi et al, 1999; Riccardiello et al, 2000). Human infections with JCV appear to be population associated: the genotype of JCV excreted by individuals of defined ethnicity is strongly

Address correspondence to Rosina Girones, Department of Microbiology, University of Barcelona, Abg. Diagona, 64508028 Barcelona, Spain. E-mail: rosina@bio.ub.es

Received 27 February 2001; revised 5 April 2001; accepted 9 April 2001. influenced by the geographical origin of the ethnic group (Agostini et al, 1997). If JCV is excreted in the urine, and a significant percentage of population is shedding this virus, it should be present and detectable, using the appropriate methodology, in urban sewage. If the viral particles are stable in the environment, JCV will also be detected in shellfish. Shellfish are organisms that act as biosensors of fecal contamination in seawater as they filtrate large volumes of water and concentrate the viral particles.

In previous studies, we have developed a methodology for detecting different viruses in environmental samples (Puig et al, 1994). We have adapted this methodology to study the presence of human polyomaviruses in sewage from different geographical areas in Europe, Africa, and the United States. The analysis of the relative viral output of a community through analysis of sewage samples could be very useful to study the regional prevalence of some viruses and future changes in the epidemiological patterns of some viral infections. 


\section{Results and discussion}

The results obtained after the analysis of the sewage samples are shown in Table 1 and reflect a very high level of excretion of JCV. Ninety-eight percent (51/52) of the samples from all the areas studied were positive for JCV at a mean concentration of $10^{2}-10^{3} \mathrm{vi}-$ ral particles $/ \mathrm{ml}$. There were no significant differences between the results obtained in each of the areas, considering that the concentration of JCV in the samples collected in the United States was particularly high. JCV was also detected in 5 of 10 shellfish samples tested. Those high levels of viruses are in accordance with the fact that JCV has been detected in $20-80 \%$ of the adult urines tested (Kitamura et al, 1994; Agostini et al, 1997) from different geographical areas. Renal JCV seems not to be latent because it is also excreted by immunocompetent individuals (Shah et al, 1997) where JCV replicates to generate progeny that is excreted in urine. So, the persistence of JCV in the kidney may be characterized by continuous viral replication and shedding.

The procedure applied is highly sensitive. The number of polyomavirus-like particles counted in a urine sample using electronic microscopy was $8.7 \times$ $10^{5}$ per $\mathrm{ml}$, and by nested PCR, the estimated sensitivity was of 5 viral particles/ml or higher.

The evaluation of the stability of JC viral particles in sewage showed that JC viral particles were present in sewage samples kept at $20^{\circ} \mathrm{C}$ during 92 days. The results of these experiments are shown in Figure 1. We have computed a linear regression model and we estimated JCV values of $\mathrm{T}_{90}$ and $\mathrm{T}_{99}$ of 26.7 days and 61.5 days, respectively. When we used DNase before the nucleic acid extraction, we found no effect showing that genomes were protected by well-structured capsids. Also, preliminary data show stability of JC viral particles in sewage samples after being exposed to $\mathrm{pH} 5$ (data not shown).

Table 1 Results obtained after analyzing 52 sewage samples for the presence of JCV

\begin{tabular}{lc}
\hline $\begin{array}{c}\text { Area } \\
\text { (number of samples) }\end{array}$ & $\begin{array}{c}\text { No. positive samples/No. total samples } \\
\text { Mean estimated concentration }\end{array}$ \\
\hline Barcelona (25) & $23 / 24$ \\
& $10^{1}-10^{2} \mathrm{PV} / \mathrm{ml}$ \\
Nancy (4) & $4 / 4$ \\
& $10^{2}-10^{3} \mathrm{PV} / \mathrm{ml}$ \\
Umê̊(4) & $4 / 4$ \\
& $10^{2}-10^{3} \mathrm{PV} / \mathrm{ml}$ \\
Pretoria (4) & $4 / 4$ \\
& $10^{1}-10^{2} \mathrm{PV} / \mathrm{ml}$ \\
El Cairo (4) & $4 / 4$ \\
& $10^{2}-10^{3} \mathrm{PV} / \mathrm{ml}$ \\
Patras (5) & $5 / 5$ \\
Washington (6) & $10^{2}-10^{3} \mathrm{PV} / \mathrm{ml}$ \\
Total samples $=52$ & $6 / 6$ \\
& $10^{3}-10^{4} \mathrm{PV} / \mathrm{ml}$ \\
& $51 / 52(98 \%)$ \\
\hline
\end{tabular}

The JC viral genomes detected were also analyzed by sequencing the regulatory (RR) and the intergenic regions (IGR). All sequences obtained from the RR of JCV detected in sewage samples and from the urine sample used as a control presented identical sequence in the 187 nucleotides analyzed, being identical with the archetypal consensus sequence. In contrast, clinical samples analyzed (CSF) presented diverse genetic rearrangements as has been described for PML-related JC viral strains (Yogo et al, 1990).

It has been also reported that archetypal JCV do not seem to be highly infective in cell cultures, although some data exist on the infection of cell cultures with archetypal strains (Hara et al, 1998). Rearranged strains seem to be those that cause PML in the brain, although archetypal strains are believed to be those that spread throughout the population and cause persistent infections. The analysis of the sequences at the regulatory region gives us information about the frequency and distribution of the JC viral types in different populations.

We analyzed $461 \mathrm{bp}$ of the IGR of 19 samples positive for JCV and 3 CSF samples from PML patients. Sequences analyzed confirmed the specificity of the nested PCR amplification. We observed differences in the IGR of the JCV sequenced. These results showed the absence of cross-contamination in our experiments. All sequenced samples from different countries in Europe, samples from the north of Africa (Egypt), and most United States samples were strongly related to those strains described in data banks as European types (Type 1). Only one of the isolates from the United States presented similarity with Asian strains (Type 2). We sequenced 2 samples from the south of Africa (Pretoria, South Africa): one presented similarity to strains previously isolated from north Africa and belonging to Type 1, whereas the other was similar to sub-Saharan types (Type 3).

The portal of entry of JCV into humans has not been elucidated. Tonsil tissue has been suggested as a possible site of the initial infection (Monaco et al, 1998) and also the digestive tract (Riccardiello et al, 2000). Our results show that JCV is persistently present in sewage and in contaminated food and the environment. Consequently, the human population is being exposed with high frequency to JCV when ingesting water and food as shellfish or vegetables exposed to fecal pollution.

JCV DNA has recently been found in different sites through the digestive tract (Riccardiello et al, 2000). It has been proven in animals using the bacteriophage M13 (Schubbert et al, 1997) that ingested noninfectious viral DNA can reach peripheral leukocytes and some organs of the human body. Not only could JC viral particles represent a source of infection, but the intake of JCV DNA through the intestine may also affect human cells. 


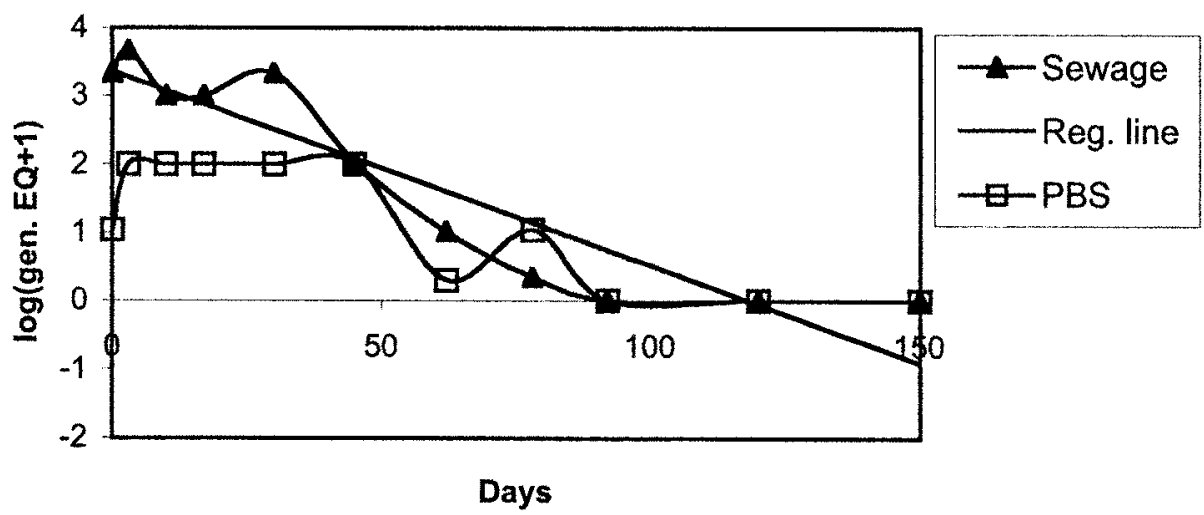

Figure 1 Stability of JCV in sewage. The regression line, the transformed values of the averages of genome equivalents detected by nested-PCR in the 3 samples (sewage), and the genome equivalents of spiked PBS control (PBS) are represented.

\section{Material and methods}

Viruses We used CSF (cerebrospinal fluid) samples donated by José Luis Pérez from the Microbiology Department of Hospital de Bellvitge, Barcelona, as positive controls. Other positive controls of JCV used in this study were obtained after concentrating in $500 \mu \mathrm{L}$ of phosphate-buffered saline (PBS) $48 \mathrm{ml}$ of urine from a healthy 38-week pregnant woman.

Sewage samples Fifty-two raw-sewage samples from different geographical areas were analyzed. Sixteen samples were collected from the sewers of Barcelona (Spain). Each sample was collected in a sterile 500-ml polyethylene container, kept at $4^{\circ} \mathrm{C}$ for less than 8 hours until the viral particles were concentrated in phosphate-buffered saline (PBS), and stored at $-80^{\circ} \mathrm{C}$.

Five samples were collected from Patras (Greece), 4 samples were collected from El Cairo (Egypt), 6 samples were collected from Washington DC (USA), 4 were collected from Umeâl(Sweden), 4 from Nancy (France), and 4 from Pretoria (South Africa). These samples were collected and shipped, frozen, to Spain, where they were concentrated in PBS and stored at $-80^{\circ} \mathrm{C}$.

Shellfish samples Four mussel samples (Mytilus galloprovincialis) and 6 oyster samples (Crassostrea gigas) were obtained from shellfish growing areas with different levels of fecal pollution located in the Delta of Ebro river, Tarragona, Spain. Shellfish sample analyses were carried out following a protocol slightly modified from Pina et al (1998) and MuniainMujika et al (2000).

Concentration of viral particles and nucleic acid extraction Following the procedure described in previous studies, we recovered viral particles from sewage samples and extracted nucleic acids (Girones et al, 1995; Pina et al, 1998). Briefly, $40 \mathrm{ml}$ of sewage sample were ultracentrifuged $(229,600 \times g$ for $1 \mathrm{~h}$ at $4^{\circ} \mathrm{C}$ ) to pellet all the viral particles together with any suspended material. Then, the sediment was eluted by mixing it with $4 \mathrm{ml}$ of $0.25 \mathrm{~N}$ glycine buffer $\mathrm{pH} 9.5$ on ice for $30 \mathrm{~min}$, and the suspended solids were separated by centrifugation at $12,000 \times g$ for $15 \mathrm{~min}$ after the addition of $5 \mathrm{ml}$ of $2 \times \mathrm{PBS}$. The viruses were finally pelleted by ultracentrifugation $(229,600 \times g$ for $1 \mathrm{~h}$ at $4^{\circ} \mathrm{C}$ ), resuspended in $0.1 \mathrm{ml}$ of $1 \times \mathrm{PBS}$, and stored at $-80^{\circ} \mathrm{C}$.

The nucleic acid extraction was based on a procedure that uses guanidinium thiocyanate (GuSCN) and adsorption of the nucleic acids to silica particles (Boom et al, 1990).

Enzymatic amplification Ten- $\mu$ l aliquots of the extracted nucleic acids were used in each test, corresponding to $4 \mathrm{ml}$ of sewage sample, $1 \mathrm{~g}$ of shellfish digestive system, $1 \mathrm{ml}$ of urine, or $10 \mu \mathrm{l}$ of CSF. Amplifications were carried out in a $50-\mu \mathrm{L}$ reaction mixture containing $10 \mathrm{mM}$ Tris- $\mathrm{HCl}\left(\mathrm{pH} 8.3\right.$ at $25^{\circ} \mathrm{C}$ ), $50 \mathrm{mM}$ $\mathrm{KCl}, 1.5 \mathrm{mM} \mathrm{MgCl}_{2}, 200 \mu \mathrm{M}$ of each dNTP, 2 units of Ampli Taq ${ }^{\circledR}$ DNA polymerase (Perkin-Elmer Cetus), and the corresponding primers $(25 \mu \mathrm{M}$ of external and internal primers). Thermal cycling of the amplification mixture was performed in a programmable heat block (Gene Amp PCR System 2400, PerkinElmer). The first cycle of denaturation was carried out for $4 \mathrm{~min}$ at $94^{\circ} \mathrm{C}$. The conditions for the 29cycle amplification were: denaturing at $92^{\circ} \mathrm{C}$ for 60 s, annealing for $60 \mathrm{~s}$, and extension at $72^{\circ} \mathrm{C}$ for $75 \mathrm{~s}$. Amplifications were completed with a 4 -min, $72^{\circ} \mathrm{C}$ extension period.

Analysis of the intergenic region (IGR) of JCV We amplified the IGR of JCV from sewage samples. External primers used for the detection of IGR were EP1A (5'-TGAATGTTGGGTTCCTGATCCCACC- $\left.{ }^{\prime}\right)$ and EP2A (5'-ACCCATTCTTGACTTTCCTAGAGAG$\left.3^{\prime}\right)$. Internal primers were P1A (5'-CAAGATATTTTGGGACACTAACAGG-3') and P2A (5'-CCAT GTCCAGAGTCTTCTGCTTCAG-3'). P1A and P2A were modified from the work of Kunitake et al (1995). The annealing temperature for first strand PCR and nested PCR were $59^{\circ} \mathrm{C}$. The results were analyzed by $3 \%$ agarose gel electrophoresis using ethidium bromide as stain. Some of the positive samples were further analyzed 
by sequencing using primers P1A, P2A, JCSR (5'TGATTACAGCATTTTTGTCTGCAAC-3'), and JCSL (5'-GGAAGTCCTTCTGTTAATTAAATCAG-3').

Analysis of the regulatory region (RR) of JCV We analyzed sewage samples for the detection of the RR of JCV to elucidate if the JCV found in environmental samples presented an archetypal regulatory region as it has been described for urinary strains or, on the contrary, it presents rearrangements of this sequence as has been described for those JCV that cause PML. Primers used were described by Monaco et al (1998). JR1 (5'-CCCTATTCAGCACTTTGTCC$\left.3^{\prime}\right)$ and JR2 (5'-CAAACCACTGTGTCTCTGTC$3^{\prime}$ ) were used as external primers and JR3 (5'-GGGAATTTCCCTGGCCTCCT-3) and JR4 (5'ACTTTCACAGAAGCCTTACG-3') as internal ones. The annealing temperature for both, first strand and nested PCR, was $54^{\circ} \mathrm{C}$. Some sewage samples positive for JCV, a urine sample used as a control and some clinical samples (CSF from PML patients) were sequenced using primers JR3 and JR4.

Sequencing of the nested-PCR products Products obtained after the nested-PCR were purified with the QUIAquick PCR purification kit (QIAGEN, Inc.). Thermal cycling of the amplification mixture was performed in a programmable heat block (Gene Amp PCR System 2400, Perkin-Elmer). Both strands of the purified DNA amplicons were sequenced with the ABI PRISM“ Dye Terminator Cycle Sequencing Ready Reaction kit with Ampli Taq ${ }^{\circledR}$ DNA polymerase FS (Perkin-Elmer, Applied Biosystems) and appropriate primers following the manufacturer's instructions. The conditions for the 25-cycle amplification were: denaturing at $96^{\circ} \mathrm{C}$ for $10 \mathrm{~s}$, annealing at $50^{\circ} \mathrm{C}$ for $5 \mathrm{~s}$, and extension at $60^{\circ} \mathrm{C}$ for $4 \mathrm{~min}$. The results were checked using the ABI PRISM 377 automated sequencer (Perkin-Elmer, Applied Biosystems). The sequences were compared with the GenBank and the EMBL (European Molecular Biology Library) using the basic BLAST program of the NCBI (The National Center for Biotechnology Information).

Nucleotide sequence accession numbers The sequences reported in this paper have been deposited in the GenBank database under accession number AF120240 to AF120242 for JCV RR sequences AF119345 to AF119356, AF304389, AF303943 to AF303948, and AF304386 to AF304388 for JCV IGR sequences.

Stability of JC viral particles in sewage samples Sewage samples and a PBS control spiked with JC viral particles present in a urine sample were kept

\section{References}

Agostini HT, Yanagihara R, Davis V, Ryschkewitsch CF, Stoner GL (1997). Asian genotypes of JC virus in Native Americans and in a Pacific Island population: markers of viral evolution and human migration. Proc Natl Acad Sci USA 94: 1454214546. in sterile containers at $20^{\circ} \mathrm{C}$. Aliquots of these samples were analyzed within a 4-month period for the presence of JC viral particles. We carried out 2 different nucleic acid extractions for each sample. In 1 of them, we added DNase prior to the extraction to destroy free DNA [25 $\mu \mathrm{l}$ of DNase buffer containing Tris-HCl pH $7.5100 \mathrm{mM}, \mathrm{MgCl}_{2} 20 \mathrm{mM}$ and $100 \mu \mathrm{g} / \mathrm{ml}$ of BSA, $25 \mu \mathrm{l}$ of viral particles, and $1 \mu \mathrm{l}$ of DNase I (Amersham Pharmacia Biotech, Inc) $10,000 \mathrm{units} / \mathrm{ml}$. We did the other DNA extraction in the same way but added $1 \mu \mathrm{l}$ of sterile water instead of DNase.

Quality control of the amplification method Direct and 10-fold dilutions of the nucleic-acid extracts were analyzed routinely on highly polluted samples in order to avoid false negatives due to inhibition of the reactions. Standard precautions were applied in all the manipulations to reduce the probability of sample contamination by amplified DNA molecules. Separate areas were used for treatment of samples, reagents, and manipulation of amplified samples. All the samples were analyzed twice in independent experiments, and a negative control was added every two samples. Sequencing of the amplified DNA in a high percentage of the samples was the final proof that we were not detecting false positives, and the differences observed in the sequence of nucleotides ruled out the possibility of crosscontamination.

\section{Acknowledgements}

This work was supported by the Center for Biologics Evaluation and Research, FDA. Sôvia BofillMas is a fellow of the Generalitat de Catalunya. We thank Serveis Cientôfico-Tècnics of the University of Barcelona for their sequencing of the PCR products. We also thank W Grabow (University of Pretoria, South Africa), L Schwartzbrod (Nancy University, France), G Wadell (Umeân University, Sweden), A Vantarakis (University of Patras, Greece), and A Shoaeb (Environmental Virology Laboratory, National Research Center, El Cairo, Egypt) for their kind collaboration in obtaining the samples in their areas. We gratefully acknowledge AM Lewis (Office of Vaccine Research and Review, CBER, FDA) for useful consultation. We also thank Rosa Bufốs for providing excellent technical assistance and G TofiñoQuesada and M Formiga-Cruz for supplying shellfish samples.
Boom R, Sol CJA, Salimans MMM, Jansen CJ, Wertheimvan Dillen PME, van der Noordaa J (1990). Rapid and simple method for purification of nucleic acids. J Clin Microbiol 28: 495-503.

Girones R, Puig M, Allard A, Lucena F, Wadell G, Jofre J (1995). Detection of adenovirus and enterovirus by PCR 
amplification in polluted waters. Water Sci Technol 31: 351-357.

Hara K, Sugimoto C, Kitamura T, Aoki N, Taguchi F, Yogo Y (1998). Archetype JC virus efficiently replicates in COS7 cells, simian cells constitutively expressing simian virus 40 T antigen. J Virol 72(7): 5335-5342.

Kitamura T, Kunitake T, Guo J, Tominaga T, Kawabe K, Yogo Y (1994). Transmission of the human polyomavirus JC virus occurs both within the family and outside the family. J Clin Microbiol 32: 2359-236.

Kunitake T, Kitamura T, Guo J, Taguchi F, Kawabe K, Yogo $\mathrm{Y}$ (1995). Parent-to-child transmission is relatively common in the spread of the human polyomavirus JC virus. J Clin Microbiol 33: 1448-1451.

Laghi L, Randolph AE, Chauhan DP, Marra G, Major EO, Neel JV, Boland CR (1999). JC virus DNA is present in the mucosa of the human colon and in colorectal cancers. Proc Natl Acad Sci USA 96: 7484-7489.

Monaco MCG, Jensen PN, Hou J, Durham LC, Major EO (1998). Detection of JC virus DNA in human tonsil tissue: evidence for site of initial viral infection. J Virol 72: 9918-9923.

Muniain-Mujika I, Girones R, Lucena F (2000). Viral contamination of shellfish: evaluation of methods and analysis of bacteriophages and human viruses. J Virol Methods 89: 109-118.
Pina S, Puig M, Lucena F, Jofre J, Girones R (1998). Viral pollution in the environment and shellfish: human adenovirus detection by PCR as an index of human viruses. Appl Environ Microbiol 64: 3376-3382.

Puig M, Jofre J, Lucena F, Allard A, Wadell G, Girones R (1994). Detection of adenoviruses and enteroviruses in polluted waters by nested PCR amplification. Appl Environ Microbiol 60: 2963-2970.

Riccardiello L, Laghi L, Ramamirtham P, Chang CL, Chang DK, Randolph AE, Boland CR (2000). JC virus DNA sequences are frequently present in human upper and lower gastrointestinal tract. Gastroenterolog 119: 12281235.

Schubbert R, Renz D, Schmitz B, Doerfler W (1997). Foreign (M13) DNA ingested by mice reaches peripheral leukocytes, spleen, and liver via the intestinal wall mucosa and can be covalently linked to mouse DNA. Proc Natl Acad Sci USA 94: 961-966.

Shah KV, Daniel RW, Strickler HD, Goedert JJ (1997). Investigation of human urine for genomic sequences of the primate polyomaviruses Simian Virus 40, BK, and JC Virus. J Infec Dis 176: 1618-1621.

Yogo Y, Kitamura T, Sugimoto C (1990). Isolation of a possible archetypal JC virus DNA sequence from nonimmunocompromised individuals. J Virol 64(6): 31393143. 